\title{
Extracellular annexins in hemostasis system
}

\author{
D. D. Zhernossekov, Y. M. Roka-Moiia, T. V. Grinenko \\ Palladin Institute of Biochemistry, NAS of Ukraine \\ 9, Leontovycha Str., Kyiv, Ukraine, 01601 \\ chemikdd@mail.ru
}

\begin{abstract}
Annexins are calcium-binding proteins that interact with cellular membranes due to their ability to bind phospholipids. The structural and functional peculiarities of these proteins have been described. Being cytosolic proteins, annexins also possess extracellular activities. However, there are some controversial opinions concerning the functional role of extracellular annexins in the human hemostasis system. We have made an attempt to summarize the latest data and consider some ideas of possible annexin application in medical practice.
\end{abstract}

Ke y w or d s: annexins, hemostasis, plasminogen/plasmin system.

Annexins are considered as a family of calcium-dependent phospholipid-binding proteins. The structure of these proteins has some common features [1] (Fig.1). As a rule, annexins possess a variable amino-terminal domain and a carboxyl core domain. The last one is typically divided into four homologous domains (each of them is about 70 amino acid residues) and each of these domains consists of five $\alpha$-helices. The amino-terminal domain contains sites for posttranslational modification and protein-protein interaction. It has to be noted that this domain provides the stability of the whole protein structure [2]. Posttranslational modifications in this region such as phosphorylation, acetylation or proteolysis make influence on the structure of key regions of the protein core even though they take place at the opposite side of the annexin molecule. The carboxyl core domain houses one or several calcium-binding motives (KGXGT-38 residues-D/E). Apart from the calcium-binding sites, in this domain there are also the sites for binding to heparin, F-actin and phospholipids (such as phosphatidyl serine and phosphatidylethanolamine). The annexins have been shown to take part in many processes: exocytosis, endocyto- sis, inhibition of blood coagulation, regulation of ion transport across membranes, membrane reorganization, vascular trafficking and redox regulation $[3,4]$. In this review we mostly paid attention to those members of annexin family that can be found in the human hemostasis system. Normally annexins are not secreted from the living cells, and the appearance of these proteins in bloodstream can be considered as a result of the cell degradation or apoptosis [5]. It is known that annexins lack the signal sequences that could direct them into the classical secretory pathway. However, for annexins A1, A2 and A5 the extracellular activity has been shown. Thus, annexin A5 is considered as an anticoagulant protein, annexin A2 as an endothelial receptor for plasminogen and tissue plasminogen activator (tPA), and annexin A1 as an anti-inflammatory agent [6].

\section{Annexin A1 and its role in inflammation}

Annexin A1 has the longest history of reported extracellular activity. It was found in human serum at some pathological states such as myocardial infarction and experimental colitis $[7,8]$. The role of annexin A1 in inflammation is related with glucocorti-

(C) 2016 D. D. Zhernossekov et al.; Published by the Institute of Molecular Biology and Genetics, NAS of Ukraine on behalf of Biopolymers and Cell. This is an Open Access article distributed under the terms of the Creative Commons Attribution License (http://creativecommons.org/licenses/by/4.0/), which permits unrestricted reuse, distribution, and reproduction in any medium, provided the original work is properly cited 


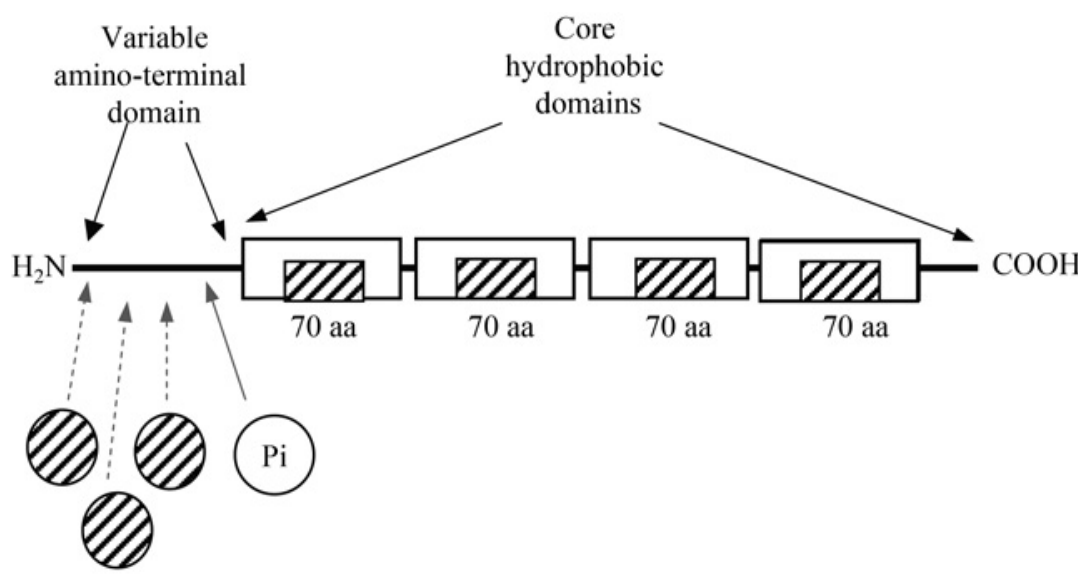

Fig. 1. Schematic representation of annexin structure:

WII, - calcium binding motive,

- binding protein,

(D) - phosphate group.

coids as the main mechanism of glucocorticoids' anti-inflammatory effects is an increase of the synthesis and function of annexin A1 [9]. Glucocorticoids bind to the cytosolic glucocorticoid receptor, a type of nuclear receptor that is activated by the ligand binding. After the hormone binds to the receptor, the newly formed complex translocates itself into the cell nucleus, where it binds to the glucocorticoid response elements in the promoter region of annexin A1 gene resulting in stimulation of the gene expression [10]. Annexin A1 inhibits phospholipase A2. This is a calcium-dependent enzyme acting on phospholipids of membranes that releases arachidonic acid from the second carbon group of glycerol. Arachidonic acid is a precursor of prostaglandins and leucotriens playing the key role in the inflammatory reactions. On the other hand, annexin A1 may be considered as a regulator of leukocyte migration $[11,12]$. As it is known, there are specific A1 receptors on the human neutrophils and monocytes [13]. They belong to the formyl peptide receptor (FRP) family of chemoattractant receptors. FRPs are the G-protein-coupled receptors, and they were identified by their ability to bind $\mathrm{N}$-formyl peptides containing an $\mathrm{N}$-terminal $\mathrm{N}$-formylmethionine produced by the degradation of either bacterial or host cells (they can be released by the mitochondria). The formyl peptide receptor (FPR) signaling pathways include the following steps: G-protein dependent activation of phospholipase $\mathrm{C}$, activation of the regulatory small GTP-ase, and activation of CD38, ectoen- zyme of the membrane surface. The final result of the process is an increase in the cytoplasmic $\mathrm{Ca}^{2+}$ level. The sustained increase of calcium is required for directed migration of the cells [14]. The sequences located in the unique N-terminal domain of annexin A1 specifically interact with the formyl peptide receptor on neutrophils, thereby eliciting the receptor-mediated intracellular responses leading to the inhibition of transendothelial migration.

\section{Annexin A2 as a receptor on leukocytes and endothelial cells}

Annexin A2 found on the surface of endothelial cells and leukocytes can function as a receptor for plasminogen and tPA acting as a positive modulator of the fibrinolytic cascade. The increased expression of annexin A2 on the surface of leukemic cells derived from the acute promyelocytic leukemia patients correlates with the clinical manifestation of bleeding [15].

Endothelial cells are thought to play a key role in the intravascular plasmin generation, as they synthetize and secrete plasminogen activators (tPA and uPA) and their inhibitors (PAI-1) [16]. It is remarkable that on endothelial cells, annexin A2 is constitutively translocated to the cell surface within 16 hours of its biosynthesis where it may consist $5 \%$ of the cellular protein pool [17]. Exogenous I ${ }^{125}$ -labeled annexin A2 bound to endothelial cell surface with high affinity (Kd 49nM) in a calcium-dependent manner. This binding may be blocked by 
peptides mimicking the classical "annexin repeat" (KGXGT) [16].

Annexin A2 is thought to be a major membrane receptor of tPA on endothelium [18]. It has been shown that tPA, plasminogen and plasmin bind to annexin A2 through protein p11 with different affinity (Kd $0.68 \mu \mathrm{M}, 0.11 \mu \mathrm{M}$ and $75 \mathrm{nM}$ respectively) [19]. There is a tight hydrophobic interaction between p11 and annexin A2. Complex p11-annexin A2 binds tPA, plasmin and plasminogen due to the $\mathrm{C}$-terminal lysine residue of the p11 molecule [1]. The formed complex can provide generation of the extracellular plasmin (plasminogen is converted into plasmin by cleaving peptide bond between Arg 561 and Val 562 by tPA) [20]. However, the proposed profibrinolytic function of annexin A2 is somewhat controversial, as there are the data, that annexin A2 in complex with p1 1 can also inhibit the plasmin activity and fibrinolysis [21].

Recently, it has been demonstrated that the tPA annexin A2 interaction may play a significant role during inflammation process (Fig.2).

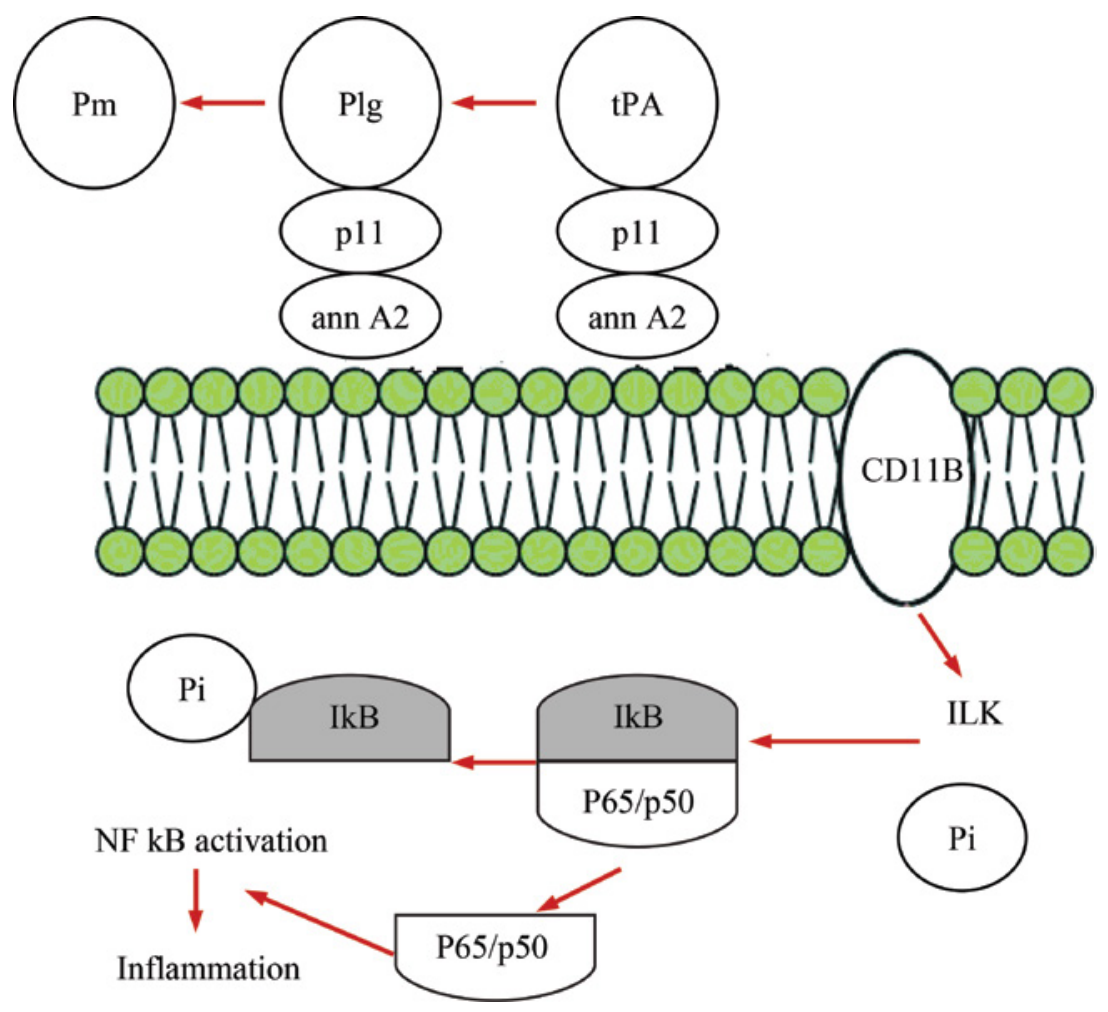

Under the stimulation of tPA, annexin A2 aggregates with $\beta-2$ integrin CD $11 \mathrm{~b}$, leading to the activation of integrin-linked kinase (ILK) pathway [22]. Thus, annexin A2 can transduce tPA signaling through its interaction with integrins. Annexin A2 mediates tPA-induced NF-kB activation in macrophages. In physiological status, the members of NF$\mathrm{kB}$ family (p50, p52, p65 and other) are retained in the cytoplasm by the specific inhibitor IkB. Upon activation, IkB becomes phosphorylated, which leads to its degradation and the release of NF-kB dimers into nuclei. It results in the subsequent DNA binding and transcription of the target proinflammatory genes. Blocking any step of this cascade (e.g. using annexin A2 antibodies) eliminates the tPA-induced NF-kB activation.

\section{Annexin A5 as an anticoagulant factor and apoptosis marker}

Annexin A5 was originally isolated from the human umbilical cord artery by virtue of its anticoagulant ac-
Fig. 2. tPA-induced NF $\mathrm{kB}$ activation in human macrophages: ann A2 - annexin A2, Plg - plasminogen, Pm - plasmin, tPA - tissue plasminogen activator, ILK integrin linked kinase, $\mathrm{Pi}$ - phosphate group. 
tivity [23]. As it was mentioned above, all calciumbinding annexins are thought to be natural anticoagulants. It is known that the phosphatidyl serine (PS) exposure on the outer membrane is the characteristic of the activated platelets or endothelial cells [24]. PS facilitates the assembly and activation of the tenase and prothrombinase complexes [25]. The annexin A5 binding to PS results in formation of an anticoagulant shield on the cell membrane [5]. This shield is of great importance for placental cells as annexin A5 binds to the apical surface of placental syncytiotrophoblasts providing maintenance of normal blood flow through the placenta. The disruption of the shield leads to the development of antiphospholipid syndrome. As a result the apical surface of placenta becomes thrombogenic and patients with antiphospholipid syndrome suffer from recurrent pregnancy losses [26]. It has also been shown that extracellular as well as cytosolic annexin A5 binds to the disrupted site of injured plasma membrane as early as a few seconds after membrane wounding and promotes membrane resealing [27]. All these data raise the question of a role of annexin A5 in the protection and repair of membrane injuries in trophoblasts.

On the other hand, annexin A5 is the main annexin of human platelets [28]. Annexin A5 binds to platelets with high affinity $(\mathrm{Kd} 7 \mathrm{nM})$ [29]. It was found that each platelet has approximately 5,000 sites to bind annexin A5. After thrombin stimulation, the amount of annexin-binding sites per platelet can reach 200,000. The treatment with phospholipase $\mathrm{C}$ or adding phospholipase preparations to the platelet mixture led to inhibition of annexin A5 binding [30]. Annexin A5 is also exposed on the apoptotic platelets [31]. During platelet apoptosis, the PS exposure occurs via the caspase and calpain activation, when platelets undergo a cellular death pathway leading to their clearance from the circulation by scavenger cells [32]. These events could be also induced in vitro by thrombin. It is remarkable, that the aging and stored platelets were also positive for PS [33]. However, it is necessary to carry out the analysis of other biomarkers to distinguish the platelet activation and apoptosis-mediated changes from each other [34].
So, annexin A5 can serve as a marker of activated or apoptotic platelets and its determination in blood and on the surface of blood cells or endothelium can be very important for the diagnosis and treatment of hemostasis disorders [35].

\section{Annexin A5 effect on plasminogen binding}

In the presence of apoptotic factors, plasminogen considerably increases phosphatidyl serine exposure. This effect was shown for monocytes and neutrophils. The increased exposure of phosphatidyl serine is associated with the growing plasminogen binding to the cell surface [36]. This effect is explained by the histone $\mathrm{H} 2 \mathrm{~B}$ exposure on the surface of apoptotic monocytes. Histone $\mathrm{H} 2 \mathrm{~B}$ has different binding sites for phosphatidyl serine and plasminogen and can provide the efficient binding of both components with the cell surface. Annexin A5 competes with histone $\mathrm{H} 2 \mathrm{~B}$ for phosphatidyl serine binding and as a result plasminogen binding to cells is inhibited.

On the other hand, the platelet activation with thrombin led to an increased exposure of phosphatidyl serine in case of platelets and, as a result, elevated plasminogen binding was observed on the platelet surface [37]. The phosphatidyl serine exposure in these experiments was detected using annexin A5. It was found a special place on the platelet surface, socalled protruding "cap", where plasminogen [37], thrombospondin and fibrinogen/fibrin were colocalized [38]. As this "cap" was also the localization place for factor XIIIa [39], it was suggested that fibrin plays a special role in amplifying the plasminogen binding to annexin A5 bound platelets [37].

However, we could also observe the plasminogen effect on the annexin A5 binding in case of activated platelets [40]. In our experiments the exogenous plasminogen preincubated with washed human platelets leads to the increased exposure of annexin A5 on the platelet surface after the thrombin stimulation. As there are no data about the formation of annexin A5-plasminogen complex, and histon $\mathrm{H} 2 \mathrm{~b}$ is not exposed on the platelet surface, the mechanism of the observed effect may be clarified only after series of further investigations. 


\section{Future perspective}

Although numerous studies clearly indicate that extracellular annexins play an important role in the functioning of human organisms, there are still many gaps in our understanding of the molecular mechanisms underlying their action. The structural peculiarities of annexins may be very important in this case. As it was shown some annexins (A2 and A5) interact with carbohydrates, in particular glycosaminoglycans. These interactions are likely to come into play only for extracellular annexins but functional significance of this binding remains to be proven $[41,42]$. On the other hand, there are some proposals for practical application of annexins in medical practice. It has been reported about diannexin, an annexin A5 homodimer that binds phosphatidyl serine with high affinity $(0.6 \mathrm{nM})$ [43]. This new preparation may find practical application in medicine due to its ability to reduce the surface area coverage by platelets perfused with human blood and to inhibit in vivo the thrombus formation and fibrin deposition in the rat and rabbit models of arterial and venous thrombosis.

There are numerous reports about the agents constructed on the annexin base as apoptotic markers [44-46]. Elevated annexin V levels have been found in acute and chronic renal conditions [47]; in patients with heart failure a high circulating annexin $\mathrm{V}$ level is likely to reflect peripheral organ damage [48]. Some annexins can be predicted as therapeutic agents. So, annexin $\mathrm{V}$ can be used in treatment of the patients with sickle cell disease [49]. There are some interesting reports concerning using annexin $\mathrm{V}$ as a potential marker in tumors [50,51] and as a therapeutic agent for the patients with diffuse large B-cell lymphoma [52].

However, future investigations are needed to clarify the precise way of the annexin turnover in human organism.

\section{REFERENCES}

1. Bharadwaj A, Bydoun M, Holloway R, Waisman D. Annexin A2 heterotetramer: structure and function. Int J Mol Sci. 2013;14(3):6259-305.
2. Lizarbe MA, Barrasa JI, Olmo N, Gavilanes F, Turnay J. Annexin-phospholipid interactions. Functional implications. Int J Mol Sci. 2013;14(2):26520-83.

3. Gerke V, Creutz CE, Moss SE. Annexins: linking $\mathrm{Ca}^{2+}$ signalling to membrane dynamics. Nat Rev Mol Cell Biol. 2005;6(6):449-61.

4. Gerke V, Moss SE. Annexins: from structure to function. Physiol Rev. 2002;82(2):331-71.

5. Petrishchev NN, Vasina LV, Lugovaya AV. Content of soluble markers of apoptosis and circulating $\mathrm{V}$ annexin-connected apoptosistic cells in the blood of patients with acute coronary syndrome. Vestnik St. Petersburg state university. 2008; ser. 2 (1): 14-23.

6. Rescher $U$, Gerke $V$. Annexins--unique membrane binding proteins with diverse functions. J Cell Sci. 2004;117(Pt 13): 2631-9.

7. Römisch J, Schüler E, Bastian B, Bürger T, Dunkel FG, Schwinn A, Hartmann AA, Pâques EP. Annexins I to VI: quantitative determination in different human cell types and in plasma after myocardial infarction. Blood Coagul Fibrinolysis. 1992;3(1):11-7.

8. Vergnolle N, Coméra C, Moré J, Alvinerie M, Buéno L. Expression and secretion of lipocortin 1 in gut inflammation are not regulated by pituitary-adrenal axis. Am J Physiol. 1997;273(2 Pt 2):R623-9.

9. Perretti $M, D^{\prime}$ 'Acquisto $F$. Annexin A1 and glucocorticoids as effectors of the resolution of inflammation. Nat Rev Immunol. 2009;9(1):62-70.

10. Revollo JR, Cidlowski JA. Mechanisms generating diversity in glucocorticoid receptor signaling. Ann N Y Acad Sci. 2009; 1179:167-78.

11. Perretti M, Chiang N, La M, Fierro IM, Marullo S, Getting SJ, Solito E, Serhan CN. Endogenous lipid- and peptide-derived anti-inflammatory pathways generated with glucocorticoid and aspirin treatment activate the lipoxin A4 receptor. Nat Med. 2002;8(11):1296-302.

12. Gavins FN, Yona S, Kamal AM, Flower RJ, Perretti M. Leukocyte antiadhesive actions of annexin 1: ALXR- and FPR-related anti-inflammatory mechanisms. Blood. 2003; 101(10):4140-7.

13. Sugimoto MA, Vago JP, Teixeira MM, Sousa LP. Annexin A1 and the Resolution of Inflammation: Modulation of Neutrophil Recruitment, Apoptosis, and Clearance. J Immunol Res. 2016;2016:8239258.

14. Panaro MA, Acquafredda A, Sisto M, Lisi S, Maffione AB, Mitolo $V$. Biological role of the N-formyl peptide receptors. Immunopharmacol Immunotoxicol. 2006;28(1):103-27.

15. Menell JS, Cesarman GM, Jacovina AT, McLaughlin MA, Lev EA, Hajjar KA. Annexin II and bleeding in acute promyelocytic leukemia. N Engl J Med. 1999;340(13):994-1004.

16. Kim J, Hajjar KA. Annexin II: a plasminogen-plasminogen activator co-receptor. Front Biosci. 2002;7:d341-8.

17. Kato J, Kuwabara Y, Mitani M, Shinoda N, Sato A, Toyama T, Mitsui A, Nishiwaki T, Moriyama S, Kudo J, Fujii Y. 
Expression of survivin in esophageal cancer: correlation with the prognosis and response to chemotherapy. Int $J$ Cancer. 2001;95(2):92-5.

18. Lin $L, H u K$. Tissue plasminogen activator and inflammation: from phenotype to signaling mechanisms. Am J Clin Exp Immunol. 2014;3(1):30-6.

19. MacLeod TJ, Kwon M, Filipenko NR, Waisman DM. Phospholipid-associated annexin A2-S100A10 heterotetramer and its subunits: characterization of the interaction with tissue plasminogen activator, plasminogen, and plasmin. J Biol Chem. 2003;278(28):25577-84.

20. Zhernosekov DD, Iusova EI, Grinenko TV. [Role of plasminogen/plasmin in functional activity of blood cells]. $U \mathrm{kr}$ Biokhim Zh (1999). 2012;84(4):5-19.

21. Fitzpatrick SL, Kassam G, Choi KS, Kang HM, Fogg DK, Waisman DM. Regulation of plasmin activity by annexin II tetramer. Biochemistry. 2000;39(5):1021-8.

22. $\operatorname{Lin} L, W u C, H u K$. Tissue plasminogen activator activates NF$\kappa \mathrm{B}$ through a pathway involving annexin A2/CD11b and integrin-linked kinase. J Am Soc Nephrol. 2012;23(8):1329-38.

23. Tzima E, Walker JH. Platelet annexin V: the ins and outs. Platelets. 2000;11(5):245-51.

24. Simák J, Holada K, Vostal JG. Release of annexin V-binding membrane microparticles from cultured human umbilical vein endothelial cells after treatment with camptothecin. BMC Cell Biol. 2002;3:11.

25. Heemskerk JW, Bevers EM, Lindhout T. Platelet activation and blood coagulation. Thromb Haemost. 2002;88(2):186-93.

26. Ueki H, Mizushina T, Laoharatchatathanin T, Terashima R, Nishimura Y, Rieanrakwong D, Yonezawa T, Kurusu S, Hasegawa Y, Brachvogel B, Pöschl E, Kawaminami M. Loss of maternal annexin A5 increases the likelihood of placental platelet thrombosis and foetal loss. Sci Rep. 2012;2:827.

27. Bouter A, Carmeille R, Gounou C, Bouvet F, Degrelle SA, Evain-Brion D, Brisson AR. Review: Annexin-A5 and cell membrane repair. Placenta. 2015;36 Suppl 1:S43-9.

28. Ramstrom S, O'Neill S, Dunne E, Kenny D. Annexin V binding to platelets is agonist, time and temperature dependent. Platelets. 2010;21(4):289-96.

29. Tait JF, Gibson D. Phospholipid binding of annexin V: effects of calcium and membrane phosphatidyl serine content. Arch Biochem Biophys. 1992;298(1):187-91.

30. Sun J, Bird P, Salem HH. Interaction of annexin V and platelets: effects on platelet function and protein $\mathrm{S}$ binding. Thromb Res. 1993;69(3):289-96.

31. van Heerde WL, Robert-Offerman S, Dumont E, Hofstra L, Doevendans PA, Smits JF, Daemen MJ, Reutelingsperger CP. Markers of apoptosis in cardiovascular tissues: focus on Annexin V. Cardiovasc Res. 2000 Feb;45(3):549-59.

32. Jackson SP, Schoenwaelder SM. Procoagulant platelets: are they necrotic? Blood. 2010;116(12):2011-8.

33. Albanyan AM, Harrison P, Murphy MF. Markers of platelet activation and apoptosis during storage of apheresis- and buffy coat-derived platelet concentrates for 7 days. Transfusion. 2009;49(1):108-17.

34. Gyulkhandanyan AV, Mutlu A, Freedman J, Leytin V. Selective triggering of platelet apoptosis, platelet activation or both. Br J Haematol. 2013;161(2):245-54.

35. Hiddink L, de Visser MC, van Heerde WL. Polymorphisms in the Annexin A5 gene influence circulating Annexin A5 levels in healthy controls. Thromb Res. 2012;129(6):815-7.

36. Das R, Plow EF. Phosphatidyl serine as an anchor for plasminogen and its plasminogen receptor, histone $\mathrm{H} 2 \mathrm{~B}$, to the macrophage surface. J Thromb Haemost. 2011;9(2):339-49.

37. Whyte CS, Swieringa F, Mastenbroek TG, Lionikiene AS, Lancé MD, van der Meijden PE, Heemskerk JW, Mutch NJ. Plasminogen associates with phosphatidyl serine-exposing platelets and contributes to thrombus lysis under flow. Blood. 2015;125(16):2568-78.

38. Abaeva AA, Canault M, Kotova YN, Obydennyy SI, Yakimenko AO, Podoplelova NA, Kolyadko VN, Chambost H, Mazurov AV, Ataullakhanov FI, Nurden AT, Alessi MC, Panteleev $M A$. Procoagulant platelets form an $\alpha$-granule proteincovered "cap" on their surface that promotes their attachment to aggregates. J Biol Chem. 2013;288(41):29621-32.

39. Mitchell JL, Lionikiene AS, Fraser SR, Whyte CS, Booth NA, Mutch NJ. Functional factor XIII-A is exposed on the stimulated platelet surface. Blood. 2014;124(26):3982-90.

40. Roka-Moiia YM, Korsa VV, Guzyk MM, Tykhomyrov AO, Zhernossekov DD. Plasminogen modulates exogenic annexin $\mathrm{V}$ binding to human platelets. In "Modern aspects of Biochemistry and Biotechnology”. Kyiv, Sanchenko. 2016:41.

41. Ishitsuka R, Kojima K, Utsumi H, Ogawa H, Matsumoto I. Glycosaminoglycan binding properties of annexin IV, V, and VI. J Biol Chem. 1998;273(16):9935-41.

42. Kassam G, Manro A, Braat CE, Louie P, Fitzpatrick SL, Waisman DM. Characterization of the heparin binding properties of annexin II tetramer. J Biol Chem. 1997; 272(24): 15093-100.

43. Rand ML, Wang H, Pluthero FG, Stafford AR, Ni R, Vaezzadeh N, Allison AC, Kahr WH, Weitz JI, Gross PL. Diannexin, an annexin A5 homodimer, binds phosphatidyl serine with high affinity and is a potent inhibitor of platelet-mediated events during thrombus formation. J Thromb Haemost. 2012;10(6):1109-19.

44. Lu C, Jiang $Q, H u M$, Tan $C$, Yu H, Hua Z. Preliminary biological evaluation of ${ }^{18} \mathrm{~F}-\mathrm{FBEM}-\mathrm{Cys}-\mathrm{Annexin} \mathrm{V}$ a novel apoptosis imaging agent. Molecules. 2015;20(3):4902-14.

45. Montón H, Parolo C, Aranda-Ramos A, Merkoçi A, Nogués $C$. Annexin-V/quantum dot probes for multimodal apoptosis monitoring in living cells: improving bioanalysis using electrochemistry. Nanoscale. 2015;7(9):4097-104.

46. Wang J, He L, Chen D, Pi Y, Zhou W, Xiong X, Ren Y, Lai Y, Hua Z. Quantitative analysis of annexin V-membrane interaction by flow cytometry. Eur Biophys J. 2015;44(5): 325-36. 
47. Jakubowska A, Kiliś-Pstrusińska K. [Importance of annexin $\mathrm{V}$ in kidney diseases]. Postepy Hig Med Dosw (Online). 2015;69:153-7.

48. Schurgers LJ, Burgmaier M, Ueland T, Schutters $K$, Aakhus S, Hofstra L, Gullestad L, Aukrust P, Hellmich M, Narula J, Reutelingsperger CP. Circulating annexin A5 predicts mortality in patients with heart failure. J Intern Med. 2016; 279(1):89-97.

49. Kennedy JR. Attenuating a sickle cell crisis with annexin V. Med Hypotheses. 2015;84(5):434-6.

50. Peng B, Guo C, Guan H, Liu S, Sun MZ. Annexin A5 as a potential marker in tumors. Clin Chim Acta. 2014;427:42-8.

51. Linke B, Abeler-Dörner L, Jahndel V, Kurz A, Mahr A, Pfrang $S$, Linke L, Krammer $P H$, Weyd $H$. The tolerogenic function of annexins on apoptotic cells is mediated by the annexin core domain. J Immunol. 2015;194(11):5233-42.

52. Wang J, Zhang Y, Liu X, Ma J, Liu P, Hu C, Zhang G. Annexin A5 inhibits diffuse large B-cell lymphoma cell invasion and chemoresistance through phosphatidylinositol 3-kinase signaling. Oncol Rep. 2014;32(6):2557-63.

\section{Позаклітинні анексини у системі гемостазу}

\section{Д. Д. Жерносєков, Я. М. Рока-Мойя, Т. В. Гриненко}

Аннесини - це кальцій-залежні протеїни, що взаємодіють 3 клітинними мембранами завдяки їх властивості зв'язувати фосфоліпіди. Структурно-функціональні особливості цих про- теїнів надані в науковій літературі. Хоча анексини - цитозольні протеїни, для них притаманна позаклітинна активність. Існують суперечливі дані стосовно ролі позаклітинних анексинів у системі гемостазу. Ми спробували систематизувати сучасні наукові дані та виявити можливе застосування анексинів у медичній практиці.

Кл юч о в і с сл о в а: анексини, гемостаз, плазміноген/плазмінова система.

\section{Внеклеточние аннексины в системе гемостаза}

Д. Д. Жерносеков, Я. М. Рока-Мойя, Т. В. Гриненко

Аннексины - это кальций-зависимые протеины, которые взаимодействуют с клеточными мембранами благодаря их способности связывать фосфолипиды. Структурно-функциональные особенности этих белков описаны в научной литературе. Хотя аннексины - цитозольные протеины, для них показана внеклеточная активность. Существуют противоречивые мнения касательно функциональной роли внеклеточних аннексинов в системе гемостаза. Мы предприняли попытку систематизировать последние научные данные и рассмотреть возможное применение аннексинов в медицинской практике.

Кл юч е в ы е с л о в а: аннексины, гемостаз, плазминоген/ плазминовая система.

Received 01.03.2016 